\title{
BENCHMARKING AGRICULTURAL AND OTHER \\ ENVIRONMENTAL PERFORMANCES OF CENTRAL AND EAST EUROPEAN COUNTRIES
}

\author{
Vladimir Radivojević ${ }^{1}$, Bojan Krstićn ${ }^{2}$, Miloš Krstićn ${ }^{3}$, Miloš Petkovićc \\ *Corresponding author E-mail: vladimir.radivojevic@ymail.com
}

A R T I C L E I N F O
Original Article
Received: 26 May 2019
Accepted: 13 June 2019
doi:10.5937/ekoPolj1902471R
UDC 005.32:[338.43+574(4-191.2:4-11)

Keywords:

environmental performances, agricultural performances, CEE countries, top 16 Europan countries

JEL: Q18, Q56, O57

\begin{abstract}
A B S T R A C T
Enhancing agricultural and other environmental performances has become an essential part of sustainable development policy in countries around the globe. Although Europe is considered as a global leader in the environmental competitiveness, the national economies within Europe region achieve different results in this field. The purpose of this paper is to evaluate current agricultural and other environmental performances of sixteen Central and East European (CEE) countries, but also to identify critical determinants for its improvement in the future period. The research is conducted through comparative analysis, benchmarking method, and correlation analysis. The data basis includes the Environmental Performance Index (2018). The research findings suggest the inferiority of CEE countries in the comparison with the bestranked European countries. The paper contributes to the sustainability literature and could serve as a practical guide in the process of formulating the development policies connected with agricultural and other environmental performances in CEE countries.
\end{abstract}

(C) 2019 EA. All rights reserved.

1 Vladimir Radivojević, PhD, Research Associate, Head of Financial Services, Ministry of Defense of the Republic of Serbia, Regional centre Niš, Beogradska street, 18000 Niš, Serbia, +381 18456 1926, vladimir.radivojevic@ymail.com, ORCID ID https://orcid. org/0000-0002-3928-0623

2 Bojan Krstić, PhD, Full Professor, University of Niš, Faculty of Economics, Trg Kralja Aleksandra Ujedinitelja no. 11, 18000 Niš, Serbia, +381 18528 685, bojan.krstic@eknfak. ni.ac.rs, ORCID ID https://orcid.org/0000-0003-4597-6819

3 Miloš Krstić, PhD, Research Associate, University of Niš, Faculty of Science and Mathematics, Višegradska street no.33,18000 Niš, Serbia,+3811845368 99, krsticmilo3@ gmail.com, ORCID ID https://orcid.org/0000-0002-5256-8613

4 Miloš Petković, MSc, Teaching Assistant, Singidunum University, Faculty of Business in Belgrade, Danijelova street no. 32, 11000 Belgrade, Serbia, +381 113093 220, mpetkovic@ singidunum.ac.rs, ORCID ID https://orcid.org/0000-0002-1989-0504 


\section{Introduction}

The entire humanity's existing system depends on the well-being of the environment. Clean air, water, plants, and food are preconditions for human health and prosperity. The main characteristic of the relationship between the environment and humanity is their interdependence. The environment affects the humanity, as well as humanity affects the environment. Consequently, the symbiosis of these interdependent categories is very important for mutual development.

Current environmental problems arise mostly from the expanding need for industrialization as a prerequisite for achieving economic growth, but also from the increasing need for urbanization as a necessity of the modern age population around the world. Furthermore, a growing global trend of industrialization and urbanization particularly in the last two decades has led to serious environmental problems worldwide. Global warming, air pollution, acid rain, urban sprawl, waste disposal, and water pollution are only some of them. These environmental problems have a significant impact on every human, plant, and animal life, no matter which part of the world or nation belongs to.

There is a clear strategic commitment of each country that advocates the concept of sustainable development to improve its environmental performance. Governmental regulations, economic measures, and applying environmental management strategies in the corporations are widespread tools that are used for this purpose in the contemporary business environment. Also, there are great efforts around the world in educating people about the importance of their small actions in the achieving national and global environmental goals. However, the awareness and the ability to implement these measures is not the same in all countries. Due to disparities in the achieved level of economic and social development, there are significant differences in agricultural and other environmental performances of particular countries.

The European Union(EU) has integrated environmental issues into the Common Agricultural Policy in order to suppress the risk of environmental degradation and improving the sustainability of agrarian ecosystems. According to the European Commission (2018), the Common Agricultural Policy beyond 2020 with the budget of $€ 365$ billion in the period 2021-2027 provides principles that are compatible with environmental requirements, but also measures that promote the development of agricultural practices preserving the environment and safeguarding the countryside. The interdependence of agriculture and environment in the EU stems from the fact that even three out of the nine specific objectives in the future agriculture policy of the EU will refer to the environment and climate, through covering the issues such as climate change, natural resources (water, soil, and air), biodiversity, habitats, and landscapes.

The purpose of this paper is to determine the achieved level of Central and East European (CEE) countries regarding to agricultural and other environmental performances. The research methodology is based on the benchmarking method, i.e. on the evaluation of all environmental performances of CEE countries in comparable perspective with 
European countries that achieve best results in this field. The aim is to identify critical factors for environmental development in CEE countries, and to establish a dynamic framework for each of these factors from the aspect of their urgency. An additional goal of the research is to examine the correlation between the results achieved by CEE countries regarding to agricultural and environmental performances. The research findings are useful for all those who influence the formulation and implementation of the agricultural and environmental policy in CEE countries.

The paper is structured in four segments. Theoretical background and literature review dealing with the environmental sustainability, its interdependence with other economic and social variables, but also the methodologies for its evaluating are presented in the first segment. The methodology and data basis are explained in the second segment. The results and discussion are submitted in the third segment. The final segment of the paper contributes conclusions.

\section{Theoretical background and literature review}

Environmental sustainability as a crucial element of sustainable development occupies a central place in considering the long-term perspective of human survival and progress. Due to such important role in the general sustainability of humanity, there is a vast economic literature on the different aspects of the environmental policy and performances. Some of them refer to the country (Jin, Zhou, Zhou, 2014; Ilić, Krstić, Jovanović, 2017; Radivojević, Krstić, Stanišić, 2018) or corporate (Wagner, Schaltegger, 2004; Gunarathne, Lee, 2015; Lisi, 2015; Dixon-Fowler et al., 2017, Latan et al., 2018; Arbolino et al., 2018) environmental performances and the methodology for evaluation of the development level in this field (Dietz, Rosa, York, 2007; York, 2009; Bogićević, Domanović, Krstić, 2016; Dizdaroglu, Yigitcanlar, 2016; Hallstedt, 2017; Fraccascia, Giannoccaro, Albino, 2017; Maceno et al., 2018). Some of them survey interdependence of environmental sustainability with other economic and social variables.

Numerous theoretical and empirical studies examine the relationship between environmental sustainability and economic growth (Bo, 2011; Ahmed, Long, 2012; Almeida et al., 2017). The theory of Kuznets (1955) termed „Environmental Kuznets Curve Hypothesis" (EKC hypothesis) is one of the most influential theories when it comes to the relationship between these categories. The main conclusion of the EKC hypothesis proves that the relationship between economic growth and its environmental impacts is not linear, and it could be illustrated by an inverted U-shaped curve. An essential reason for such interdependence of these categories is reflected in the idea that ,economic growth causes negative ecological impacts that initially tend to increase as the economy grows, until they reach a turning point, where the environmental damage stabilizes and begins to fall while economic growth continues“" (Almeida et al., 2017, p. 119).

Similar results are obtained in the studies that test the relationship between various pollutants and economic variables such as income, economic growth, and economic development. For example, the impact of economic growth on $\mathrm{CO}_{2}$ emissions is 
examined in various countries (Zhao et al., 2013), Pakistan (Ahmed, Long, 2013), Mongolia (Ahmed, 2014), and Australia (Marques, Fuinhas, Leal, 2018). Jha and Murthy (2003) consider interdependence between global environmental degradation and economic development in 174 countries. Li et al. (2014) emphasize the relationship between farmland conversion and economic growth in post-reform China. Lopez and Mitra (2000) examine the implications of corruption and rent-seeking behavior by the government for the relationship between pollution and growth. The results of all these studies confirm the existence of the EKC hypothesis among the variables both in the long-run and short-run. Similar research findings are summarized in the study of Mukherjee and Chakraborty (2013) when it comes to the relationships among environmental quality, human development, and political and governance regimes in a cross-country framework.

Continuous monitoring and evaluating agricultural and other environmental performances at different levels are important preconditions for the implementation of appropriate measures and policies for its improvement. There is a large body of literature attend to the measuring these performances. One of the widely accepted methodologies for evaluating environmental performances (that includes agriculture as one of its issues) of countries is based on the Environmental Performance Index. It is a composite index developed by environmental experts at the Yale University and Columbia University, which ranks countries around the globe according to policy objectives, issue categories, and indicators corresponding to environmental health and ecosystem vitality.

\section{Methodology and data basis}

The purpose of this paper is to evaluate the agricultural and other environmental performances of CEE countries. The research is conducted through benchmarking the performances of CEE countries with the performances of European countries that achieved the best results in environmental sustainability. Evaluating of agricultural and environmental performances and formulating policy and strategies using the benchmarking method is a challenging task for researchers. It is valuable method that allows the national economy to identify critical factors that contribute to superior performances. The ambition of benchmarking method in this paper is to establish a framework within which indicators and best practices would be examined in order to determine issue categories of CEE countries' environmental performances that can be improved.

The group of CEE countries consists of following sixteen countries: Albania, Bosnia and Herzegovina, Bulgaria, Croatia, Czech R., Estonia, Hungary, Latvia, Lithuania, Montenegro, N. Macedonia, Poland, Romania, Serbia, Slovak R., and Slovenia. A benchmark group of countries is composed of following sixteen best-ranked European countries in terms of environmental performances: Austria, Belgium, Denmark, Finland, France, Germany, Iceland, Ireland, Italy, Luxembourg, Malta, Norway, Spain, Sweden, Switzerland, and the United Kingdom. 
The data basis for the research consists of the secondary data of the Environmental Performance Index (EPI) published by Yale Center for Environmental Law and Policy of Yale University and Center for International Earth Science Information Network of Columbia University in the annual report (2018). The 2018 EPI ranks 180 countries on 24 environmental performance indicators within 10 issue categories (that are grouped in two policy objectives - „Environmental health“ and „Ecosystem vitality“) as follows:

Environmental health:

[1] Air quality (that has 3 indicators),

[2] Water and sanitation (2 indicators),

[3] Heavy metals (1 indicator),

Ecosystem vitality:

[4] Biodiversity and habitat (6 indicators),

[5] Forests (1 indicator),

[6] Fisheries (2 indicators),

[7] Climate and energy (5 indicators),

[8] Air pollution (2 indicators),

[9] Water resources (1 indicator), and

[10] Agriculture (1 indicator).

Using these EPI metrics provides identifying and understanding best policies and practices in top-ranked economies in order to formulate the guidance for CEE countries that aspire to achieve high environmental performances in the future.

\section{Results and discussions}

In order to evaluate the environmental performances of CEE countries, it is presented the data about the rank and score of EPI (2018) for all CEE countries in Table 1. Beside the score and global rank of CEE countries according to EPI as a composite index, Table 1. shows the rank of each country in the isolated group of CEE countries, but also the score and global rank of these countries according to Environmental health and Ecosystem vitality as two EPI policy objectives. 
Table 1. The score and rank of CEE countries according to the EPI (2018)

\begin{tabular}{|c|c|c|c|c|c|c|c|}
\hline \multirow{2}{*}{ Country } & \multirow{2}{*}{$\begin{array}{c}\text { EPI score } \\
(0-100)\end{array}$} & \multirow{2}{*}{$\begin{array}{l}\text { EPI global } \\
\text { rank } \\
\text { (out of 180) }\end{array}$} & \multirow{2}{*}{$\begin{array}{c}\text { Rank } \\
\text { on the list } \\
\text { of isolated } \\
\text { group } \\
\text { of CEE } \\
\text { countries }\end{array}$} & \multicolumn{2}{|c|}{$\begin{array}{c}\text { Environmental } \\
\text { health }\end{array}$} & \multicolumn{2}{|c|}{ Ecosystem vitality } \\
\hline & & & & Score & $\begin{array}{c}\text { Global } \\
\text { rank }\end{array}$ & Score & $\begin{array}{c}\text { Global } \\
\text { rank }\end{array}$ \\
\hline Slovak R. & 70.60 & 28 & 1 & 63.87 & 89 & 75.08 & 3 \\
\hline Lithuania & 69.33 & 29 & 2 & 72.57 & 57 & 67.18 & 21 \\
\hline Bulgaria & 67.85 & 30 & 3 & 69.60 & 66 & 66.68 & 24 \\
\hline Czech R. & 67.68 & 33 & 4 & 68.69 & 69 & 67.01 & 22 \\
\hline Slovenia & 67.57 & 34 & 5 & 72.34 & 58 & 64.40 & 33 \\
\hline Latvia & 66.12 & 37 & 6 & 72.80 & 54 & 61.66 & 49 \\
\hline Albania & 65.46 & 40 & 7 & 65.67 & 82 & 65.32 & 30 \\
\hline Croatia & 65.45 & 41 & 8 & 67.04 & 77 & 64.39 & 34 \\
\hline Hungary & 65.01 & 43 & 9 & 57.67 & 107 & 69.90 & 12 \\
\hline Romania & 64.78 & 45 & 10 & 58.67 & 105 & 68.85 & 15 \\
\hline Estonia & 64.31 & 48 & 11 & 73.24 & 51 & 58.35 & 59 \\
\hline Poland & 64.11 & 50 & 12 & 58.71 & 104 & 67.72 & 18 \\
\hline Montenegro & 61.33 & 65 & 13 & 72.61 & 55 & 53.81 & 87 \\
\hline N. Macedonia & 61.06 & 68 & 14 & 67.43 & 74 & 56.82 & 64 \\
\hline Serbia & 57.49 & 84 & 15 & 61.18 & 100 & 55.03 & 77 \\
\hline $\begin{array}{l}\text { Bosnia and } \\
\text { Herzegovina }\end{array}$ & 41.84 & 158 & 16 & 63.87 & 89 & 27.15 & 179 \\
\hline
\end{tabular}

Source: 2018 Environmental Performance Index Report

The data presented in Table 1. indicate that all CEE countries except Bosnia and Herzegovina are achieved the score of EPI that places them in the first half of global ranking. The situation is similar in the case of the score of CEE countries in two EPI policy objectives. Namely, the score of Ecosystem vitality puts Bosnia and Herzegovina in the place that is before the last $\left(179^{\text {th }}\right.$ place of 180 observed countries $)$. Also, Hungary, Romania, Poland, and Serbia have poorer performances in terms of Environmental health than the first half of the global list.

Slovak R. as $28^{\text {th }}$ country in the EPI global ranking reaches the highest score in the CEE group (70.60). This country records particularly impressive performances in the Ecosystem vitality of EPI, where it achieved $3^{\text {rd }}$ best score in the global terms (75.08). Slovak R. is followed by second-ranked Lithuania (69.33), and third-ranked Bulgaria (67.85). The first three CEE countries are followed by Czech R. (67.68), Slovenia (67.57), Latvia (66.12), Albania (65.46), Croatia (65.45), Hungary (65.01), Romania (64.78), Estonia (64.31), Poland (64.11), Montenegro (61.33), N. Macedonia (61.06), Serbia (57.49), and Bosnia and Herzegovina (41.84).

With the aim to estimate the agricultural and other environmental performances of CEE countries in the comparative perspective, the authors decided to present the results of the best-ranked European countries according to these performances in the global terms. It is indicative that the 16 best-ranked European countries are at the same time 
16 best-ranked countries in the world. Table 2. shows the scores of top 16 Europan countries in all ten issue categories within the EPI.

Table 2. The scores of top 16 European countries in the issue categories within the EPI (2018)

\begin{tabular}{|c|c|c|c|c|c|c|c|c|c|c|c|c|}
\hline Country & 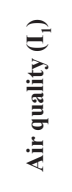 & 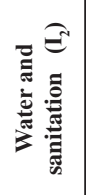 & 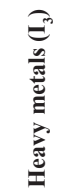 & 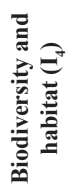 & 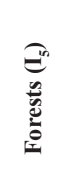 & 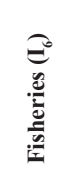 & 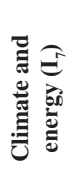 & 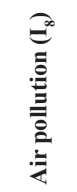 & 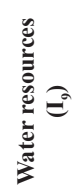 & 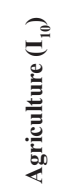 & $\frac{5}{3}$ & 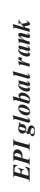 \\
\hline Switzerland & 91.06 & 99.99 & 87.77 & 84.20 & 47.40 & - & 90.55 & 98.70 & 99.67 & 43.87 & 87.42 & 1 \\
\hline France & 95.97 & 97.22 & 83.29 & 96.25 & 25.08 & 57.71 & 70.46 & 96.82 & 95.56 & 67.77 & 83.95 & 2 \\
\hline Denmark & 99.16 & 97.78 & 88.30 & 94.48 & 12.74 & 50.75 & 67.56 & 71.00 & 98.45 & 67.02 & 81.60 & 3 \\
\hline Malta & 94.40 & 100.00 & 48.74 & 87.77 & - & 56.49 & 67.04 & 57.32 & 100.00 & 32.62 & 80.90 & 4 \\
\hline Sweden & 92.84 & 96.88 & 100.00 & 81.00 & 5.53 & 53.76 & 86.80 & 64.17 & 98.49 & 55.12 & 80.51 & 5 \\
\hline United Kingdom & 94.43 & 100.00 & 93.09 & 96.69 & 6.90 & 42.16 & 63.06 & 82.87 & 99.82 & 57.34 & 79.89 & 6 \\
\hline Luxembourg & 93.62 & 99.30 & 88.55 & 96.54 & 18.77 & - & 58.53 & 61.82 & 99.76 & 38.06 & 79.12 & 7 \\
\hline Austria & 82.21 & 94.63 & 91.08 & 91.69 & 27.60 & - & 62.79 & 86.31 & 99.08 & 71.34 & 78.97 & 8 \\
\hline Ireland & 95.78 & 100.00 & 73.18 & 88.63 & 8.78 & 71.14 & 54.16 & 87.23 & 91.19 & 61.94 & 78.77 & 9 \\
\hline Finland & 99.00 & 100.00 & 100.00 & 89.25 & 5.98 & 61.11 & 62.33 & 49.10 & 97.01 & 49.97 & 78.64 & 10 \\
\hline Iceland & 98.55 & 100.00 & 86.99 & 75.77 & - & 39.30 & 61.96 & 49.11 & 94.47 & 59.78 & 78.57 & 11 \\
\hline Spain & 94.07 & 100.00 & 61.27 & 95.66 & 8.95 & 43.14 & 67.77 & 69.34 & 99.71 & 29.74 & 78.39 & 12 \\
\hline Germany & 84.09 & 96.74 & 100.00 & 96.92 & 34.99 & 47.71 & 55.47 & 93.30 & 99.65 & 61.21 & 78.37 & 13 \\
\hline Norway & 97.14 & 99.65 & 96.44 & 88.96 & 22.08 & 68.73 & 63.58 & 24.76 & 96.11 & 28.51 & 77.49 & 14 \\
\hline Belgium & 88.63 & 96.09 & 58.60 & 95.70 & 15.61 & 46.69 & 63.81 & 79.02 & 98.08 & 47.61 & 77.38 & 15 \\
\hline Italy & 80.56 & 100.00 & 70.23 & 94.10 & 30.96 & 37.99 & 65.14 & 88.55 & 97.53 & 49.03 & 76.96 & 16 \\
\hline $\begin{array}{l}\text { Average score of } \\
\text { top } 16 \text { group }\end{array}$ & 92.59 & 98.64 & 82.97 & 90.85 & 19.38 & 52.05 & 66.31 & 72.46 & 97.79 & 51.31 & - & - \\
\hline
\end{tabular}

Source: 2018 Environmental Performance Index Report

Table 2. presents impressive results of top 16 European countries in the environmental performances. With 16 countries in the world's top 16, Europe region is an undisputed leader in the environmental performances. Switzerland convincingly reaches the highest global score of EPI (87.42), while France record second-best score (83.95), and Denmark third-best score (81.60) of EPI. The first three European countries are followed by Malta (80.90), Sweden (80.51), United Kingdom (79.89), Luxembourg (79.12), Austria (78.97), Ireland (78.77), Finland (78.64), Iceland (78.57), Spain (78.39), Germany (78.37), Norway (77.49), Belgium (77.38), and Italy (76.96). The supremacy is also evident in the fact that even seven countries in the Europe top 16 group achieved a maximum score of 100 in the Water and sanitation issue (Malta, United Kingdom, Ireland, Finland, Iceland, Spain, and Italy), three in Heavy metals issue (Sweden, Finland, and Germany), while Malta reached that score in Water resources issue.

Considering the previous analysis, it is obvious that the comparison of environmental performances of any group of countries with the top 16 European countries leads to the conclusion about the inferiority of the first one. However, such a comparison allows the identification of possibilities for improvement in the group of inferior countries. 
Accordingly, Table 3. shows the scores of CEE countries in the issue categories within the EPI in the comparison with the top 16 European countries.

Table 3. The scores of CEE countries in the issue categories within the EPI in the comparison with the top 16 European countries (2018)

\begin{tabular}{|c|c|c|c|c|c|c|c|c|c|c|c|c|}
\hline Country & 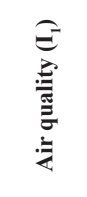 & 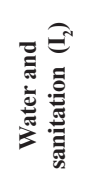 & 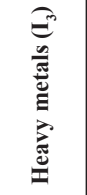 & 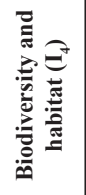 & 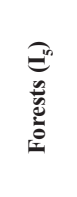 & 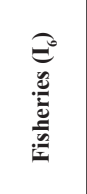 & 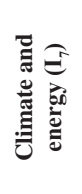 & 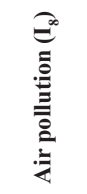 & 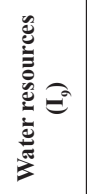 & 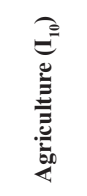 & $\frac{0}{3}$ & $\underset{\mathbf{\Sigma}}{\mathbf{\Sigma}}$ \\
\hline Slovak R. & 59.42 & $69.62^{*}$ & $87.21^{\#}$ & $94.31^{\#}$ & 17.09 & - & $74.21^{\#}$ & $79.51^{\#}$ & $89.95^{*}$ & $61.53^{\#}$ & 70.60 & 28 \\
\hline Lithuania & $77.97^{*}$ & 58.51 & $86.63^{\#}$ & $93.83^{\#}$ & 7.75 & $57.83^{\#}$ & $62.46^{*}$ & 59.73 & $93.49^{*}$ & $62.01^{\#}$ & 69.33 & 29 \\
\hline Bulgaria & $68.49^{*}$ & $71.26^{*}$ & 74.15 & $93.39^{\#}$ & $34.38^{\#}$ & $62.17^{\#}$ & $56.04^{*}$ & 52.91 & $93.93^{*}$ & 43.68 & 67.85 & 30 \\
\hline Czech R. & $65.77^{*}$ & $69.98^{*}$ & $98.82^{\#}$ & $94.96^{\#}$ & 17.18 & - & 54.65 & 57.07 & $95.77^{*}$ & $62.17^{\#}$ & 67.68 & 33 \\
\hline Slovenia & $71.25^{*}$ & $70.59^{*}$ & $97.00^{\#}$ & $95.78^{\#}$ & $30.87^{\#}$ & - & 51.16 & 49.85 & $88.50^{*}$ & 34.85 & 67.57 & 34 \\
\hline Latvia & $77.66^{*}$ & 60.62 & $82.78^{*}$ & $92.05^{\#}$ & 3.67 & 50.65 & 42.89 & $84.31^{\#}$ & $96.30^{*}$ & $45.68^{*}$ & 66.12 & 37 \\
\hline Albania & $65.47^{*}$ & 66.56 & 62.89 & 75.37 & $23.36^{\#}$ & $58.25^{\#}$ & $68.36^{\#}$ & $86.07^{\#}$ & $80.73^{*}$ & 22.61 & 65.46 & 40 \\
\hline Croatia & 64.07 & $70.01^{*}$ & $87.84^{\#}$ & $95.25^{\#}$ & $34.36^{\#}$ & $54.55^{\#}$ & 54.41 & 43.23 & $86.58^{*}$ & $47.68^{*}$ & 65.45 & 41 \\
\hline Hungary & 52.30 & 66.26 & 75.88 & $91.70^{\#}$ & 11.64 & - & $61.68^{*}$ & $75.22^{\#}$ & $93.42^{*}$ & $69.15^{\#}$ & 65.01 & 43 \\
\hline Romania & 57.37 & 59.90 & 68.25 & $90.80^{*}$ & $27.82^{\#}$ & 48.86 & $68.53^{\#}$ & $71.20^{*}$ & $83.95^{*}$ & $48.15^{*}$ & 64.78 & 45 \\
\hline Estonia & $78.87^{*}$ & 58.45 & $88.82^{\#}$ & $92.39^{\#}$ & 4.56 & $76.04^{\#}$ & 33.62 & 54.29 & $96.42^{*}$ & 40.75 & 64.31 & 48 \\
\hline Poland & 53.04 & $69.23^{*}$ & 69.29 & $96.37^{\#}$ & 14.26 & 42.66 & $64.33^{*}$ & $72.30^{*}$ & $92.35^{*}$ & 43.37 & 64.11 & 50 \\
\hline Montenegro & $69.28^{*}$ & $78.61^{\circ}$ & $79.89^{*}$ & 73.77 & $30.77^{\#}$ & 36.18 & 46.85 & 59.22 & $81.67^{*}$ & 10.57 & 61.33 & 65 \\
\hline North Macedonia & $66.43^{*}$ & $69.16^{*}$ & 70.11 & 64.85 & $30.62^{\#}$ & - & $63.85^{*}$ & 56.99 & 52.07 & 35.99 & 61.06 & 68 \\
\hline Serbia & 56.67 & $69.73^{*}$ & 68.53 & 49.84 & $38.66^{\#}$ & - & $61.77^{*}$ & 59.76 & 60.49 & $52.95^{\#}$ & 57.49 & 84 \\
\hline $\begin{array}{l}\text { Bosnia and } \\
\text { Herzegovina }\end{array}$ & 60.37 & $71.54^{*}$ & 63.39 & 26.93 & $49.31^{\circ}$ & - & 26.80 & 30.79 & 0 & 33.09 & 41.84 & 158 \\
\hline $\begin{array}{l}\text { The highest score } \\
\text { in CEE group }\end{array}$ & $\begin{array}{l}78.87 \\
\text { Eston. }\end{array}$ & $\begin{array}{l}78.61 \\
\text { Mont. }\end{array}$ & $\begin{array}{l}98.82 \\
\text { Czech }\end{array}$ & $\begin{array}{c}96.37 \\
\text { Poland } \\
\end{array}$ & $\begin{array}{l}49.31 \\
B \& H \\
\end{array}$ & $\begin{array}{c}76.04 \\
\text { Eston. }\end{array}$ & $\begin{array}{c}74.21 \\
\text { Slovak }\end{array}$ & $\begin{array}{l}86.07 \\
\text { Alban. }\end{array}$ & $\begin{array}{c}96.42 \\
\text { Eston. }\end{array}$ & $\begin{array}{l}69.15 \\
\text { Hung. }\end{array}$ & - & - \\
\hline $\begin{array}{l}\text { Average score of } \\
\text { CEE group }\end{array}$ & 65.28 & 67.50 & 78.84 & 82.60 & 23.52 & 54.13 & 55.73 & 62.03 & 80.35 & 44.64 & - & - \\
\hline $\begin{array}{l}\text { The highest score } \\
\text { in top } 16 \text { group }\end{array}$ & $\begin{array}{l}99.16 \\
\text { Den. }\end{array}$ & $\begin{array}{l}100.00 \\
7 \text { coun. }\end{array}$ & $\begin{array}{l}100.00 \\
3 \text { coun. }\end{array}$ & $\begin{array}{l}96.92 \\
\text { Germ. }\end{array}$ & $\begin{array}{l}47.40 \\
\text { Switz. }\end{array}$ & \begin{tabular}{|c|}
71.14 \\
Ireland \\
\end{tabular} & $\begin{array}{l}90.55 \\
\text { Switz. }\end{array}$ & $\begin{array}{l}98.70 \\
\text { Switz. }\end{array}$ & $\begin{array}{l}100.00 \\
\text { Malta }\end{array}$ & $\begin{array}{c}71.34 \\
\text { Austria }\end{array}$ & - & - \\
\hline $\begin{array}{l}\text { Average score of } \\
\text { top } 16 \text { group }\end{array}$ & 92.59 & 98.64 & 82.97 & 90.85 & 19.38 & 52.05 & 66.31 & 72.46 & 97.79 & 51.31 & - & - \\
\hline
\end{tabular}

Source: 2018 Environmental Performance Index Report

Legend:

Indicates that the score is below the average score of the CEE group.

* Indicates that the score is above the average score of the CEE group.

\# Indicates that the score is above the average score of top 16 European countries.

0 Indicates that the score is above the score of the best country in the group of top 16 European countries.

Data showed in Table 3. indicate the domination of top 16 European countries over the CEE countries in terms of environmental performances. CEE countries achieved a better average score than top 16 European countries in two (Forests and Fisheries) out of ten EPI issue categories. Top 16 European countries reached a higher average score in another eight issue categories. The biggest lag of CEE countries is recorded in Water and sanitation issue (even 31.14), followed by Air quality (27.31), and Water resources 
(17.44) issues. Furthermore, there is not CEE country which reaches the average score of top 16 European countries in these three issues.

On the other hand, at least three CEE countries achieved a better score than the average score of top 16 European countries in another seven issues. The minimum number of three CEE countries have higher score in Climate and energy issue, while a maximum number of the ten CEE countries reach better result in Biodiversity and habitat issue category. Moreover, Bosnia and Herzegovina recorded the score above the best country in the group of top 16 European countries in Forests issue.

The conclusions of previous analysis provide a useful foundation for identification of critical issue categories of EPI for each CEE country, but also for the determination of its improvement priorities in terms of time. There are two important notes for further analysis. First, each issue category of EPI in which CEE country achieved score that is below the score of the best country in the group of top 16 European countries is considered as a critical issue category. Second, there are three priority levels when it comes improvement of critical issue categories. The first priority level includes issues which score is below the average score of CEE countries. The improvement of these issues is urgent. The second priority level consists of issues which score is between the average score of CEE countries and the average score of top 16 European countries. The third priority level introduces issues which score is between the average score of top 16 European countries and the score of the best-positioned European country. Table 4. specifies the critical issues of EPI in CEE countries according to priority levels.

Table 4. Specification of the EPI critical issues in CEE countries according to priority levels

\begin{tabular}{|c|c|c|c|c|}
\hline Country & $\begin{array}{c}\text { The first } \\
\text { priority level }\end{array}$ & $\begin{array}{l}\text { The second } \\
\text { priority level }\end{array}$ & $\begin{array}{l}\text { The third } \\
\text { priority level }\end{array}$ & $\begin{array}{l}\text { Total number of } \\
\text { critical issues }\end{array}$ \\
\hline Slovak R. & $\mathrm{I}_{1}, \mathrm{I}_{5}$ & $\mathrm{I}_{2}, \mathrm{I}_{0}$ & $\mathrm{I}_{3}, \mathrm{I}_{4}, \mathrm{I}_{7}, \mathrm{I}_{8}, \mathrm{I}_{10}$ & 9 \\
\hline Lithuania & $\mathrm{I}_{2}, \mathrm{I}_{5}, \mathrm{I}_{8}$ & $\mathrm{I}_{1}, \mathrm{I}_{7}, \mathrm{I}_{9}$ & $\mathrm{I}_{3}, \mathrm{I}_{4}, \mathrm{I}_{6}, \mathrm{I}_{10}$ & 10 \\
\hline Bulgaria & $\mathrm{I}_{3}, \mathrm{I}_{8}, \mathrm{I}_{10}$ & $\mathrm{I}_{1}, \mathrm{I}_{2}, \mathrm{I}_{7}, \mathrm{I}_{9}$ & $\mathrm{I}_{4}, \mathrm{I}_{5}, \mathrm{I}_{6}$ & 10 \\
\hline Czech R. & $\mathrm{I}_{5}, \mathrm{I}_{7}, \mathrm{I}_{8}$ & $\mathrm{I}_{1}, \mathrm{I}_{2}, \mathrm{I}_{2}$ & $\mathrm{I}_{3}, \mathrm{I}_{4}, \mathrm{I}_{10}$ & 9 \\
\hline Slovenia & $\mathrm{I}_{7}, \mathrm{I}_{8}, \mathrm{I}_{10}$ & $\mathrm{I}_{1}, \mathrm{I}_{2}, \mathrm{I}_{9}$ & $\mathrm{I}_{3}, \mathrm{I}_{4}, \mathrm{I}_{5}$ & 9 \\
\hline Latvia & $\mathrm{I}_{2}, \mathrm{I}_{5}, \mathrm{I}_{6}, \mathrm{I}_{7}$ & $\mathrm{I}_{1}, \mathrm{I}_{3}, \mathrm{I}_{9}, \mathrm{I}_{10}$ & $\mathrm{I}_{4}, \mathrm{I}_{8}$ & 10 \\
\hline Albania & $\mathrm{I}_{2}, \mathrm{I}_{3}, \mathrm{I}_{4}, \mathrm{I}_{10}$ & $\mathrm{I}_{1}, \mathrm{I}_{0}$ & $\mathrm{I}_{5}, \mathrm{I}_{6}, \mathrm{I}_{7}, \mathrm{I}_{8}$ & 10 \\
\hline Croatia & $\mathrm{I}_{1}, \mathrm{I}_{7}, \mathrm{I}_{8}$ & $\mathrm{I}_{2}, \mathrm{I}_{9}, \mathrm{I}_{10}$ & $\mathrm{I}_{3}, \mathrm{I}_{4}, \mathrm{I}_{5}, \mathrm{I}_{6}$ & 10 \\
\hline Hungary & $\mathrm{I}_{1}, \mathrm{I}_{2}, \mathrm{I}_{3}, \mathrm{I}_{5}$ & $\mathrm{I}_{7}, \mathrm{I}_{9}$ & $\mathrm{I}_{4}, \mathrm{I}_{8}, \mathrm{I}_{10}$ & 9 \\
\hline Romania & $\mathrm{I}_{1}, \mathrm{I}_{2}, \mathrm{I}_{3}, \mathrm{I}_{6}$ & $\mathrm{I}_{4}, \mathrm{I}_{8}, \mathrm{I}_{0}, \mathrm{I}_{10}$ & $\mathrm{I}_{5}, \mathrm{I}_{7}$ & 10 \\
\hline Estonia & $\mathrm{I}_{2}, \mathrm{I}_{5}, \mathrm{I}_{7}, \mathrm{I}_{8}, \mathrm{I}_{10}$ & $\mathrm{I}_{1}, \mathrm{I}_{9}$ & $\mathrm{I}_{3}, \mathrm{I}_{4}, \mathrm{I}_{6}$ & 10 \\
\hline Poland & $\mathrm{I}_{1}, \mathrm{I}_{3}, \mathrm{I}_{5}, \mathrm{I}_{6}, \mathrm{I}_{10}$ & $\mathrm{I}_{2}, \mathrm{I}_{7}, \mathrm{I}_{8}, \mathrm{I}_{0}$ & $\mathrm{I}_{4}$ & 10 \\
\hline Montenegro & $\mathrm{I}_{4}, \mathrm{I}_{6}, \mathrm{I}_{7}, \mathrm{I}_{8}, \mathrm{I}_{10}$ & $\mathrm{I}_{1}, \mathrm{I}_{2}, \mathrm{I}_{3}, \mathrm{I}_{0}$ & $\mathrm{I}_{5}$ & 10 \\
\hline N. Macedonia & $\mathrm{I}_{3}, \mathrm{I}_{4}, \mathrm{I}_{8}, \mathrm{I}_{9}, \mathrm{I}_{10}$ & $\mathrm{I}_{1}, \mathrm{I}_{2}, \mathrm{I}_{7}$ & $\mathrm{I}_{5}$ & 9 \\
\hline Serbia & $\mathrm{I}_{1}, \mathrm{I}_{3}, \mathrm{I}_{4}, \mathrm{I}_{8}, \mathrm{I}_{9}$ & $\mathrm{I}_{2}, \mathrm{I}_{7}$ & $\mathrm{I}_{5}, \mathrm{I}_{10}$ & 9 \\
\hline $\begin{array}{l}\text { Bosnia and } \\
\text { Herzegovina }\end{array}$ & $\mathrm{I}_{1}, \mathrm{I}_{3}, \mathrm{I}_{4}, \mathrm{I}_{7}, \mathrm{I}_{8}, \mathrm{I}_{9}, \mathrm{I}_{10}$ & $\mathrm{I}_{2}$ & - & 8 \\
\hline
\end{tabular}


Paradoxically, Bosnia and Herzegovina as the worst-ranked country in the CEE group has the least critical issues of EPI ( 8 critical issues in total) in comparison with other countries within this group (Table 4.). When it comes to Forests issue, Bosnia and Herzegovina achieved a better result than the best-positioned country in the group of top 16 European countries. However, this country has the largest number of critical issues in the first priority level ( 7 critical issues), i.e. the most of environmental performances that need to be urgently improved in order to increase its rank in the CEE group of countries. All other CEE countries have a maximum critical issues ( 9 or 10 critical issues depend on the number of EPI issues observed in a particular country).

Slovak R. as the best-ranked country in the CEE group has the least critical issues in the first priority level ( 2 critical issues). This country has the same number of critical issues in the second priority level, while third priority level includes 5 critical issues. It means that Slovak R. needs urgent actions in Air quality and Forests issues in order to reach the average score of CEE countries. After the achieving that goal, Slovak R. should improve Water and sanitation and Water resources issues with the aim to meet the average score of the top 16 European countries. When mentioned target is accomplished, the priority should be to improve Heavy metals, Biodiversity and habitat, Climate and energy, Air pollution, and Agriculture issues in order to reach the results of the best-ranked country in the top 16 European group. Each CEE country should set a framework for improvement of environmental performances as it described in the case of Slovak R.

The data presented in Table 3. and Table 4. show that Air pollution issue needs urgent actions in ten out of sixteen CEE countries. The Heavy metals and Agriculture issues require improvement in the short term in eight CEE countries. Seven CEE countries have Air quality, Forests and Climate and energy issues in the first priority level. The Water and sanitation needs urgent actions in six CEE countries, while Biodiversity and habitat issue in five countries from this group. Lastly, four out of sixteen CEE countries have Fisheries issue in the first priority level, while Water resources require improvement in the short term in three CEE countries.

CEE countries recorded a lower average score in the Agriculture issue category than top 16 European countries for 6.67, which is not much lagging compared to the other issue categories (see Table 3.). Also, data from Table 4. show that the Agriculture issue is in the first priority level in eight CEE countries, in the second priority level in three CEE countries, and in the third priority level in five CEE countries. It is indicative that five out of six worst-ranked CEE countries (Estonia, Poland, Montenegro, N. Macedonia, and Bosnia and Herzegovina) have Agriculture issue in the first priority level. It could be considered as a potential indicator of significant correlation between the Agriculture issue and EPI scores of CEE countries.

In order to examine correlation between the scores achieved by CEE countries in the Agriculture issue category and EPI, the method of Pearson's correlation analysis is applied (Table 5.). 
Table 5. Pearson's correlation coefficient between scores of CEE countries in the Agriculture issue category and EPI (2018)

\begin{tabular}{|c|c|c|c|}
\hline & & EPI & Agriculture \\
\hline \multirow{3}{*}{ EPI } & Pearson's Correlation & 1 & $0.355(* *)$ \\
\hline & Sig. (2-tailed) & & .177 \\
\hline & $\mathrm{N}$ & 16 & 16 \\
\hline \multirow{3}{*}{ Agriculture } & Pearson's Correlation & $0.355(* *)$ & 1 \\
\hline & Sig. (2-tailed) & .177 & \\
\hline & $\mathrm{N}$ & 16 & 16 \\
\hline
\end{tabular}

Source: Author's calculation (SPSS 24)

The value of Pearson's correlation coefficient of 0.355 presented in Table 5. indicates a relatively weak correlation between the scores of CEE countries in the Agriculture issue category and EPI in 2018. However, the result of correlation analysis is not statistically significant (Sig. 2-tailed 0.05).

\section{Conclusions}

This paper aims to analyze agricultural and other environmental performances of CEE countries in the comparable perspective. Research findings suggest that most countries in Central and East Europe achieve above-average results in the global competitiveness of the agriculture and environment. Precisely, all CEE countries except Bosnia and Herzegovina are reached the score of EPI (2018) that places them in the first half of global ranking. The analysis of the achieved scores in two EPI policy objectives indicates similar results. Only Bosnia and Herzegovina is positioned in the second half of global ranking according to the Ecosystem vitality, while Hungary, Romania, Poland, and Serbia have poorer performances in terms of Environmental health than the first half of the global list.

The best-positioned country in the CEE group is Slovak R., which occupies $28^{\text {th }}$ place in the world with the EPI score of 70.60. This country records particularly impressive performances in the Ecosystem vitality of EPI, where it achieved $3^{\text {rd }}$ best score in the global terms (75.08). On the opposite, Bosnia and Herzegovina with the EPI score of 41.84 is convincingly the worst-ranked CEE country in the world $\left(158^{\text {th }}\right.$ place). This country achieves a better score than the average of the CEE group in only two out of ten issue categories (Water and sanitation and Forests). Between these extremes (Slovak R. and Bosnia and Herzegovina) are positioned other CEE countries in the following order: Lithuania (69.33), Bulgaria (67.85), Czech R. (67.68), Slovenia (67.57), Latvia (66.12), Albania (65.46), Croatia (65.45), Hungary (65.01), Romania (64.78), Estonia (64.31), Poland (64.11), Montenegro (61.33), N. Macedonia (61.06), and Serbia (57.49).

The results of the applied benchmarking method indicate the inferiority of CEE countries in the comparison with the top 16 European countries. CEE countries achieved a better average score than top 16 European countries in only two (Forests and Fisheries) out of ten EPI issue categories. The biggest lag of CEE countries is recorded in Water and sanitation issue (even 31.14), followed by Air quality (27.31) and Water resources (17.44) issues. 
Beside mentioned results, the benchmarking method serves as framework for identification of possibilities for improvement of environmental performances in each CEE country, but also for determination of urgency or time priority in its improvement. The analysis shows that Air pollution issue needs urgent actions in ten CEE countries, while Heavy metals issue requires improvement in the short term in eight CEE countries. Such as Heavy metals issue, Agriculture is in the first priority level in eight CEE countries, but also in the second priority level in three CEE countries, and in the third priority level in five CEE countries. Briefly, the research findings of applied benchmarking provide the formulation of national strategies, actions, and their time frame for each CEE country in order to improve its agricultural and other environmental performances in the future.

Finally, the results of correlation analysis indicate a relatively weak correlation between the scores of CEE countries in the Agriculture issue category and EPI in 2018.

\section{Acknowledgements}

Paper is a part of research within the project no. 179066 entitled „Improving the competitiveness of the public and private sector by networking competences in the process of European integration of Serbia“, financed by the Ministry of Education, Science and Technological Development of the Republic of Serbia.

\section{Conflict of interests}

The authors declare no conflict of interest.

\section{References}

1. Ahmed, K. (2014). Environmental Kuznets curve for $\mathrm{CO}_{2}$ emission in Mongolia: An empirical analysis. Management of Environmental Quality: An International Journal, 25(4), 505-516. https://doi.org/10.1108/MEQ-03-2013-0017

2. Ahmed, K., \& Long, W. (2012). Environmental Kuznets Curve and Pakistan: An empirical analysis. Procedia Economics and Finance, 1, 4-13. https://doi. org/10.1016/S2212-5671(12)00003-2

3. Ahmed, K., \& Long, W. (2013). An empirical analysis of CO2 emission in Pakistan using EKC hypothesis. Journal of International Trade Law and Policy, 12(2), 188-200. https://doi.org/10.1108/JITLP-10-2012-0015

4. Almeida, T.A.d.N., Cruzb, L., Baratab, E., \& García-Sánchez, I.M. (2017). Economic growth and environmental impacts: An analysis based on a composite index of environmental damage. Ecological Indicators, 76, 119-130. http://dx.doi. org/10.1016/j.ecolind.2016.12.028

5. Arbolino, R., De Simone, L., Carlucci, F., Yigitcanlar, T., \& Ioppolo, G. (2018). Towards a sustainable industrial ecology: Implementation of a novel approach in the performance evaluation of Italian regions. Journal of Cleaner Production, 178, 220-236. https://doi.org/10.1016/j.jclepro.2017.12.183

6. Bo, S., 2011. A literature survey on Environmental Kuznets Curve. Energy Procedia, 5, 1322-1325. https://doi.org/10.1016/j.egypro.2011.03.229 
7. Bogićević, J., Domanović, V., \& Krstić, B. (2016). The role of financial and nonfinancial performance indicators in enterprise sustainability evaluation. Ekonomika, 62(3), 1-13. doi:10.5937/ekonomika1603001B

8. Dietz, T., Rosa, E.A., \& York, R. (2007). Driving the human ecological footprint. Frontiers in Ecology and the Environments, 1, 13-18.

9. Dixon-Fowler, H.R., Ellstrand, A.E., \& Johnson, J.L. (2017). The role of board environmental committees in corporate environmental performance. Journal of Business Ethics, 140(3), 423-438. https://doi.org/10.1007/s10551-015-2664-7

10. Dizdaroglu, D., \& Yigitcanlar, T. (2016). Integrating urban ecosystem sustainability assessment into policy-making: Insights from the Gold Coast City. Journal of Environmental Planning and Management, 59, 1982-2006. http://dx.doi.org/10.1 080/09640568.2015.1103211

11. European Commission. Agriculture and the environment: Introduction, Retrieved from https://ec.europa.eu/agriculture/envir en (April 20, 2019).

12. European Commission (2018). EU Budget: the Common Agricultural Policy beyond 2020. Fact Sheet, Retrieved from http://europa.eu/rapid/press-release MEMO-183974 en.pdf (April 20, 2019).

13. Fraccascia, L., Giannoccaro, I., \& Albino, V. (2017). Rethinking resilience in industrial symbiosis: Conceptualization and measurements. Ecological Economics, 137, 148-162. http://dx.doi.org/10.1016/j.ecolecon.2017.02.026

14. Gunarathne, N., \& Lee, K.-H. (2015). Environmental Management Accounting (EMA) for environmental management and organizational change. Journal of Accounting and Organizational Change, 11(3), 362-383. https://doi.org/10.1108/ JAOC-10-2013-0078

15. Hallstedt, S.I. (2017). Sustainability criteria and sustainability compliance index for decision support in product development. Journal of Cleaner Production, 140, 251-266. http://dx.doi.org/10.1016/j.jclepro.2015.06.068

16. Ilić, I., Krstić, B., \& Jovanović, S. (2017). Environmental performances of agriculture in the European Union countries. Economics of Agriculture, 64(1), 41-55.

17. Jha, R., \& Murthy, K.V.B. (2003). An inverse global environmental Kuznets curve. Journal of Comparative Economics, 31(2), 352-368. https://doi.org/10.1016/ S0147-5967(03)00042-8

18. Jin, J., Zhou, D., \& Zhou, D. (2014). Measuring environmental performance with stochastic environmental DEA: The case ofAPEC economies. Economic Modelling, 38, 80-86. https://doi.org/10.1016/j.econmod.2013.12.017

19. Kuznets, S. (1955). Economic growth and income inequality. American Economic Review, 45, 1-28.

20. Latan, H., Jabbour, C.J.C., Jabbour, A.B.L.d.S. Samuel Fosso Wamba, S.F., \& Shahbaz, M. (2018). Effects of environmental strategy, environmental uncertainty and top management's commitment on corporate environmental performance: The role of environmental management accounting. Journal of Cleaner Production, 180, 297-306. https://doi.org/10.1016/j.jclepro.2018.01.106 
21. Li, Y., Chen, C., Wang, Y., \& Liu, Y. (2014). Urban-rural transformation and farmland conversion in China: The application of the environmental Kuznets Curve. Journal of Rural Studies, 36, 311-317. https://doi.org/10.1016/j.jrurstud.2014.10.005

22. Lisi, I.E. (2015). Translating environmental motivations into performance: The role of environmental performance measurement systems. Management Accounting Research, 29(1), 27-44. https://doi.org/10.1016/j.mar.2015.06.001

23. Lopez, R., \& Mitra, S. (2000). Corruption pollution, and the Kuznets environment curve. Journal of Environmental Economics and Management, 40(2), 137-150. https://doi.org/10.1006/jeem.1999.1107

24. Maceno, M.M.C., Pawlowski, U., Machado, K.S., \& Seleme, R. (2018). Environmental performance evaluation - A proposed analytical tool for an industrial process application. Journal of Cleaner Production, 172, 1452-1464. https://doi.org/10.1016/j.jclepro.2017.10.289

25. Marques, A.C., Fuinhas, J.A., \& Leal, P.A. (2018). The impact of economic growth on $\mathrm{CO}_{2}$ emissions in Australia: The environmental Kuznets curve and the decoupling index. Environmental Science and Pollution Research, 25(27), 27283-27296. https://doi.org/10.1007/s11356-018-2768-6

26. Mukherjee, S., \& Chakraborty, D. (2013). Is environmental sustainability influenced by socioeconomic and sociopolitical factors? Cross-country empirical analysis. Sustainable Development, 21(6), 353-371.

27. Radivojević, V., Krstić, B., \& Stanišić, T. (2018). Environmental sustainability: Implications and limitations in Western Balkan countries. Journal of Sustainable Development, 2(1), 23-35.

28. Wagner, M., \& Schaltegger, S. (2004). The effect of corporate environmental strategy choice and environmental performance on competitiveness and economic performance: An empirical study of EU manufacturing. European Management Journal, 22(5), 557-572. https://doi.org/10.1016/j.emj.2004.09.013

29. York, R. (2009). The Challenges of Measuring Environmental Sustainability: Comment on „Political and Social Foundations for Environmental Sustainability“. Political Research Quarterly, 62(1), 205-208.

30. Zhao, F., Xu, M., Zheng, Y., Wong, M.H.G., \& Chi, Y. (2013). Improving the environmental Kuznets curve for evaluating the relationships between carbon dioxide emissions and economic development. Journal of Food, Agriculture and Environment, 11(2), 1193-1199.

31. Yale Center for Environmental Law \& Policy of Yale University, Center for International Earth Science Information Network of Columbia University (2018). 2018 Environmental Performance Index Report, Retrieved from https:/epi. envirocenter.yale.edu/epi-topline (April 15, 2019). 